\title{
Effect of computer aided instruction on students' interest in selected topics in electronic libraries course in federal tertiary institutions in Anambra State, Nigeria
}

\author{
*Obiora Nwosu, prof. \\ University Librarian \\ E-mail: obiora4christ@gmail.com \\ Cell: +2348037089060 \\ *Angela Ifeoma Ndanwu \\ Serials Librarian \\ *Festus Aghagbo Nwako Library \\ Nnamdi Azikiwe University, Awka, Nigeria \\ E-mail: ndanwaangela@gmail.com \\ Cell: +2348083108982
}

\begin{abstract}
The purpose of this study was to find out the effect of computer aided instruction on the interest of students in electronic libraries course. The population consisted of 100 electronic libraries students in Library and Information Science Departments in federal tertiary institutions in Anambra State, Nigeria.A27 item structured questionnaire was used for data collection. It was subjected to content validity by experts in Computer Science, Library and Information Science, Vocational Education and Measurement and Evaluation. Two research questions and two hypotheses were formulated to guide the study. The study adopted quasi-experimental design. Pretest-posttest equivalent groups was used. The sample for the study consisted of sixty third year library and information science students. The internal consistency of the instrument was determined using KuderRichardson Formular 21 which yielded a reliability coefficient of 0.92 . Mean and standard deviation were used to answer the research question. Experimental group was taught through computer aided instruction whereas control group was taught through modified lecture method. On the completion of six weeks, the level of interest of the two groups was determined. The findings revealed that the computer aided instruction method of teaching enhanced students' interest in electronic libraries than the modified lecture method. It was recommended that lecturers should adopt the use of computer aided instruction in teaching of electronic libraries in tertiary institutions in order to enhance students' interest in electronic libraries.
\end{abstract}

Keywords: Computer aided instruction, Students' interest, Electronic libraries, ICT, Anambra State, Nigeria

\section{Introduction}

"Electronic Libraries" is a course offered in Library and Information Science programmes. Electronic Libraries is also known as Internet and Electronic Libraries course. The study of Electronic Libraries from its inception was through verbal description of course content, which made the study very abstract and quite uninteresting (Sani, 2017). The undue emphasis on theoretical aspect of Electronic Libraries to the detriment of practical, power point exposure, computer exposure, multimedia concept and project approach had made the course very abstract and also uninteresting. The none utilization of the foregoing teaching tools/methods by lecturers could result in production of ill equipped graduates as they would lack practical component of the course. Effective instructional strategy appears to be a solution to students irrespective of their gender differences in library and information science course.

Despite the importance of Electronic Libraries in equipping learners with information and communication technology (ICT)skills, it should be noted 
Obiora Nwosu and Angela Ifeoma Ndanwu: Effect of computer aided instruction on students' interest in selected topics in electronic libraries course in federal tertiary institutions in Anambra State, Nigeria

that students are gradually losing interest in the course(Ndanwu, 2020).

Interest could be defined as the "focusing of the sense organs on or giving attention to some person, activity, situation or object" (Essien, Akpan\&Obot, 2015)." Interest could also be regarded as the feeling one has in the cause of wanting to know or learn more about somebody or something.It differs from the person's attitude which refers to the manner of behaving towards somebody/something. Interest is an emotional and affective state that defines individuals responsiveness to a given event, situation, activity, object or person (Olodu, 2012).

Computer aided instruction (CAI) stands for the type of instruction carried out with the help of a computer as a machine. "Computer Aided Instructionis defined as an interaction between a student, computer controlled display and a response entry device for the purpose of achieving educational outcomes" (Qureshi, 2020). According to Adeyemi(2012), CAI programs use drill and practice, problem solving, tutorials and simulation approaches to present topics that best test the students' understanding. It is learner-centered and activity-oriented. The major objective of CAI is to enable all learners maximize their learning achievement, characterized by adaptability of instruction to the learner needs They further opined that CAI instruction is learner centered provides self-pacing, has multiple user approach with random access facilities for revision and updating. It is indeed a medium of instruction(Okoli\&Onyeagba, 2016)..

CAI has been found to enhance students' interest than conventional method in teaching and learning of physics. Nwanneh and Agommuoh (2017) conducted a study on the effect of CAI on students' interest and achievement in physics in Imo State, Nigeria and found thatCAI had significant effect on students' interest and achievement in physics; that application of computer technology to all aspects of human endeavor coupled with the need to create student-centered classroom to engage learners in their learning tasks improved learners' interest and achievement in the school subjects has necessitated the use of computer assisted instruction(CAI) in teaching physics.

"Gender simply means the character or characteristics of being male or female, man or woman, boy or girl (male or female) "(Ukala, 2018). Researchers have 'revealed that gender influences students' academic achievement in CAI. For example, Ismail (2010) observed that males and females respond differently to computer aided instruction. Idowu (2018) argued against the findings of Ismail and stressed that computer programme lack specific gender attributes so it would be very unlikely that male and female learners will vary in their response to computer aided instructions.

Modified lecture method is a traditional/conventional method of teaching. Modified lecture method is a teaching method in which the presenter/lecturer teaches orally to a group of class participants and creates a break in the lecture during the process of teaching and learning in order to give room for relevant demonstrations' or activities (Dimgba, 2016). "Modified lecture method is planned to overcome some of the drawbacks of a formal lecture (George,2014). It is a type of lecture method and it is mostly used in tertiary institutions. According to Kufi (2015), there is no best method for teaching "Electronic Libraries" in tertiary institutions. What is important is the ability of the lecturer to make up for the weaknesses of whatever method he wants to adopt. A number of instructional strategies/methods have been tried in the school system, yet there is persistent low interest in "Electronic Libraries" (Uwem, 
Obiora Nwosu and Angela Ifeoma Ndanwu: Effect of computer aided instruction on students' interest in selected topics in electronic libraries course in federal tertiary institutions in Anambra State, Nigeria

2017). As other teaching methods may not be yielding the desired result, this researcher decided to use the teaching methods that involves computer to see if that will improve the students' interest. The effect of computer aided instruction needs to be investigated to ascertain its effect on Library and Information Science students' interest.

\section{Purpose of the study}

The purpose of this study was to find out the effect of computer aided instruction (CAI) on the academic achievement and interest of students on electronic libraries course federal tertiary institutions in Anambra State, Nigeria. Specifically, the study determined the following:

1. Effect of computer aided instruction on interest of tertiary institution students in Electronic Libraries course in Anambra State, Nigeria.

2. Effect of computer aided instruction on interest of male and female students in electronic libraries course.

\section{Research questions}

The following research questions were posed to guide the study:

1. What are the effects of computer aided instruction method of teaching on interest of tertiary institution students in electronic libraries course in Anambra State, Nigeria?

2. What are the effects of computer aided instruction on interest of male and female students in electronic libraries course?

\section{Hypotheses}

The following null hypotheses were tested at 0.05 level of significance in the study:

1. There is no significant difference in the posttest interest mean scores of students taught electronic libraries using computer aided instruction and those taught with modified lecture method in tertiary institutions in Anambra State, Nigeria.

2. There is no significant difference in the posttest interest mean scores of male and female students taught electronic libraries using computer aided instruction.

3. There is no significant interaction effect of teaching methods and gender on students' interest in electronic libraries course.

\section{Methods}

The population of this study is all the third year Library and Information Science students in the federal tertiary institutions in Anambra State, Nigeria offering electronic libraries course. Purposive sampling technique was used to select two (2) federal tertiary institutions out of three federal tertiary institutions in Anambra State. Using purposive sampling technique, third year Library and Information Science students in Nnamdi Azikiwe University, Awka and Federal College of Education (Technical), Umunze in their intact classes were chosen for the study. This was because the two schools had functional computer facilities and electric power supply. The third institution (Federal Polytechnic, Oko) was dropped because it was not a degree awarding institute. All the students in each of the two intact classes were 60 in number. With a flip of coin, one of the two institutions was assigned to experimental group and the other as the control group. Experimental group was made up of 30 students( 6 males and 24 females) while control group was made up of 30 students(4 males and 26 females). The study employed a quasi-experimental research design implemented by a pre-test post-test control group containing intact,

Library and Information Perspectives and Research, Volume 2, Number 1, 2020 
Obiora Nwosu and Angela Ifeoma Ndanwu: Effect of computer aided instruction on students' interest in selected topics in electronic libraries course in federal tertiary institutions in Anambra State, Nigeria

non-equivalent groups of students(30) thirty in the experimental group and thirty (30) in the control group. The sample consisted of 60 students. Data for the study were collected using a 27 item" Electronic Libraries Interest Scale (ELIS)" developed by the researchers.

The face validity of ELIS was done by six experts from Departments of Library and Information Science, Measurement and Evaluation, Curriculum, Computer Science and Vocational Education, all in Nnamdi Azikiwe University, Awka, Nigeria. Based on their suggestions some of the items were modified to suit the purpose of the study. Content validity of the instrument was also ascertained by adopting the Bloom's taxonomy of educational objective. The 27- item interest scale was developed by the researcher. It is provided with a 5pointLikert rating Scale. The students were expected to indicate their extent of agreement or disagreement among the twenty seven item statements on the units of the study in electronic libraries. The Reliability of the Electronic Libraries Interest Scale was used to measure students 'general interest in electronic libraries, based on their attraction and like for electronic libraries.

In order determine the reliability of the instrument, the ELIS items were trialtested. The data gathered were analyzed and subjected to a reliability test by using the Kuder-Richardson (K-R) formular ' 21 ' to establish the reliability of the instrument. The instrument yielded an internal consistency of 0.92

The schedule of the experiment is as follows:

The students were given the ELIS.

The schedule of the experiment is as follows:

Week

Week 1

Week 2

Week 3

Week 4

Week 5

Week 6
Activities

Familiarization and pre-ELIS administration

Teaching of the selected topic in both tertiary schools

Teaching of the selected topic in both tertiary schools

Teaching of the selected topic in both tertiary schools

Teaching of the selected topic in both tertiary schools

-Post- ELIS administration
A. Teaching of the Lesson: the subject lecturer in both schools assisted the researcher in order to facilitate to prevent bias that may be introduced by teacher effect.

B. Administration of Test Instrument: ELIS were administered as pre-test both to experimental and control groups before treatment. The Electronic Libraries Interest Scale (ELIS) was administered to the experimental group after the treatment in other to determine their level of interest in electronic libraries likewise the control group.
Copies of the ELIS were administered to the students before treatment began as pre-tests. Students' scores in the pre-tests showed their initial standing before treatment. At the end of treatment period, the items of the instrument were re-arranged and produced so as not to make the students test wise and re-administered to the student as posttest. The pre-test scores served as covariates to the post-test scores.

The answer to the research questions was provided using mean and standard deviation while the hypotheses were tested with analysis of covariance(ANCOVA) at 0.05 level of 
Obiora Nwosu and Angela Ifeoma Ndanwu: Effect of computer aided instruction on students' interest in selected topics in electronic libraries course in federal tertiary institutions in Anambra State, Nigeria

significance. In this case, the pretest and posttest mean scores were used. The difference between the pretest interest mean score and posttest interest mean score indicates the effect of computer aided instruction on students' interest.

\section{Results}

The results of the study are presented according to the research questions and hypotheses.
Research question one: What is the effect of computer aided instruction method of teaching on students' interest score in electronic libraries course in Anambra State, Nigeria?

The date in Table 1 are used to answer this question.

Table 1: Mean difference and standard deviation of the pre-test and post-test scores of students in the experimental and control groups on the effect of CAI on students' interest in electronic libraries course

\begin{tabular}{|c|c|c|c|c|c|c|}
\hline \multirow[t]{2}{*}{ S/nGroup } & \multirow[t]{2}{*}{$\mathrm{n}$} & \multicolumn{2}{|l|}{ Pre-test } & \multicolumn{2}{|l|}{ Post-test } & Mean \\
\hline & & $\overline{\mathrm{x}}$ & SD & $\overline{\mathrm{x}}$ & SD & Difference \\
\hline 1Experimental & 30 & 39.93 & 12.61 & 66.73 & 16.91 & 26.80 \\
\hline 2 Control & 30 & 27.63 & 17.95 & 40.87 & 16.30 & 13.24 \\
\hline
\end{tabular}

The data in Table 1 is a summary of the mean pre-test and post-test scores of students in the experimental and control groups. The result shows that the mean pre-test and mean post-test scores of students in the experimental group who were taught with Computer aided Instruction method of teaching are 39.93 and 66.73 respectively with standard deviation of 12.61 and 16.91 respectively. Table 1 also show that the mean pre-test and mean post-test scores of students in the control group who were taught with modified lecture method are 27.63 and 40.87 respectively with standard deviation of 17.95 and 16.30 respectively. It could be observed that students in the experimental group had a higher mean gain of 26.80 as against 13.24 obtained by those in the control group. This result suggests that the Computer aided Instruction method of teaching enhances students' interest in electronic libraries than the modified lecture method.

Research question two: What is the effect of computer aided instruction method of teaching on the interest of male and female students in electronic libraries?

Data related to research question 2 are presented in Table 2 
Obiora Nwosu and Angela Ifeoma Ndanwu: Effect of computer aided instruction on students' interest in selected topics in electronic libraries course in federal tertiary institutions in Anambra State, Nigeria

Table 2: Mean and standard deviation of pre-test and post-test scores of male and female students in the experimental and control groups on the effects of CAI on the interest of the students in electronic libraries course

\begin{tabular}{|c|c|c|c|c|c|c|c|}
\hline \multirow[t]{2}{*}{ S/n Group } & \multirow[t]{2}{*}{ Gender } & \multirow[t]{2}{*}{$\mathbf{n}$} & \multicolumn{2}{|l|}{ Pre-test } & \multicolumn{2}{|l|}{ Post-test } & Mean \\
\hline & & & $\overline{\mathbf{x}}$ & SD & $\overline{\mathbf{x}}$ & SD Di & ence \\
\hline \multirow[t]{2}{*}{ 1Experimental } & Male & 8 & 33.25 & 12.33 & 54.00 & 16.14 & 20.75 \\
\hline & Female & 22 & 42.36 & 12.07 & 71.36 & 14.96 & 29.00 \\
\hline \multirow[t]{2}{*}{2 Control } & Male & 6 & 23.33 & 11.71 & 34.67 & 10.33 & 11.34 \\
\hline & Female & 24 & 28.7083 & 19.25 & 42.42 & 17.31 & 13.71 \\
\hline
\end{tabular}

Table 2 presents the mean pre-test and mean post-test scores of male and female students in the experimental and control groups in the Electronic Libraries Interest Scale. The result showed that the mean gain in the scores of male and female students in the experimental groups are20.75 and 29.00 respectively. The corresponding figures for those in the control group are 11.34 and 13.71 respectively. It could be observed that the mean gain for female students in the experimental group is higher than that of male students. This result suggests that the
Computer aided Instruction method of teaching enhancefemale students' interest in Electronic Libraries more than the modified lecture method of teaching.

Hypothesis one: There is no significant difference in the post-test mean interest scores of students taught electronic libraries using computer aided instruction method and those taught with modified lecture method

Data related to hypothesis are presented in Table 3

Table 3: Summary of analysis of covariance (ANCOVA) test for significant difference in the post-test mean interest scores of students taught electronic libraries using computer aided instruction method and those taught with modified lecture method

\begin{tabular}{lllllll}
\hline Source & $\begin{array}{l}\text { Sum of } \\
\text { Squares }\end{array}$ & Df & $\begin{array}{l}\text { Mean } \\
\text { Square }\end{array}$ & F & Sig. & Decision \\
\hline Corrected Model & & 2 & 1583.52 & 2 & 10791.76 & 138.11 \\
& 0.00 & & & & & \\
Intercept & 5406.99 & 1 & 5406.99 & 69.19 & 0.00 & \\
Pretest & 11547.25 & 1 & 11547.25 & 147.77 & 0.00 & $*$ \\
GROUP & 2779.95 & 1 & 2779.95 & 35.58 & 0.00 & $* S$ \\
Error & 4454.09 & 57 & 78.14 & & & \\
Total & 199704.00 & 60 & & & & \\
Corrected Total & 26037.60 & 59 & & & & \\
*S = Significant at 0.05 level of significance
\end{tabular}

Table 3 presents a summary of the analysis of covariance conducted to test for significant difference in the mean post-test interest scores of students in electronic libraries between those in the experimental and control groups with pre-test used as covariates. The students were divided into two groups by teaching methods namely experimental (computer aided instruction method) and control group(modified lecture method). As shown, the F-value for group (or teaching method) is 35.58 with 
Obiora Nwosu and Angela Ifeoma Ndanwu: Effect of computer aided instruction on students' interest in selected topics in electronic libraries course in federal tertiary institutions in Anambra State, Nigeria

level of significance being 0.00 . On this basis, the null hypothesis is rejected implying that there is significant difference in the post-test mean interest scores of students in the experimental and control groups who were taught with the computer aided instruction method and the modified lecture method respectively. The significant difference is attributed to the experimental group which obtained a higher mean post-test interest score in electronic libraries as shown in Table 2.

Hypothesis two: There is no significant difference in the post test mean interest scores of male and female students taught electronic libraries using computer aided Instruction method and those taught with modified lecture method

Data related to hypothesis two are presented in Table 4

Table 4: Summary of analysis of covariance (ANCOVA) test for significant difference in the post-test mean interest scores of male and female students taught electronic libraries using computer aided instruction method and those taught with modified lecture method

\begin{tabular}{|c|c|c|c|c|c|c|}
\hline Source & $\begin{array}{l}\text { Sum of } \\
\text { Squares }\end{array}$ & Df & $\begin{array}{l}\text { Mean } \\
\text { Square }\end{array}$ & $\mathrm{F}$ & Sig. & Decision \\
\hline Corrected Mode & 18965.19 & 2 & 9482.59 & 76.43 & 0.00 & \\
\hline Intercept & 3237.61 & 1 & 3237.61 & 26.09 & 0.00 & \\
\hline Pretest & 17771.31 & 1 & 17771.31 & 143.23 & 0.00 & \\
\hline Gender & 161.62 & 1 & 161.62 & 1.30 & $0.26^{*}$ & NS \\
\hline Error & 7072.41 & 57 & 124.08 & & & \\
\hline Total & 199704.00 & 60 & & & & \\
\hline Corrected Total & 26037.60 & 59 & & & & \\
\hline
\end{tabular}

$* \mathrm{NS}=$ Not Significant at 0.05 level of significance

Table 4 presents a summary of the analysis of covariance conducted to test for significant difference in the mean post-test interest scores of male and female students in Electronic Library. As shown, the Fvalue for gender is 1.30 with level of significance being 0.26 . Since the obtained level of significance $(0.26)$ is greater than the stipulated probability level of 0.05 , the hypothesis is upheld. This implies thatthere is no significant difference in the post test mean interest scores of male and female students taught electronic libraries using computer aided instruction method and those taught with modified lecture method.

\section{Discussion}

Evidence from this study has shown that computer aided instruction method of teaching enhances students interest than modified lecture method. Two factors which could likely enhance interest of students in electronic libraries class are the nature and level of activities in the class and the familiarity of the curriculum materials. The high interest rate shown between the two groups may have been due to opportunity provided for the students in conjunction with computer aided instruction, Zhao (2014) explained that students learning interest can be aroused through the use of new teaching methods, and making students to pay attention to classroom teaching design and add the interestingness of classroom teaching. Thus computer aided instruction has the ability of arousing and sustaining students' interest in electronic libraries more than modified lecture method.

The test of hypotheses shows that there is significant difference in the post- 
Obiora Nwosu and Angela Ifeoma Ndanwu: Effect of computer aided instruction on students' interest in selected topics in electronic libraries course in federal tertiary institutions in Anambra State, Nigeria

test mean interest scores of students in the experimental and control group who were taught with the computer aided instruction method and the modified lecture method. This implies that computer aided instruction method of teaching enhance students' interest in electronic libraries than the modified lecture method. The results of this study with respect to interest is in line with the previous findings of Chinwendu and Agommuoh (2017) who reported that CAI had significant effects on students' interest and achievement in Physics.

In line with this study, Nwanne and Agommuoh (2017), in their study on the effect of computer assisted instruction (CAI) on students' interest and achievement in Physics, found that CAI had significant effects on students' interest and achievement in Physics, where students in the CAI group achieved more.

The findings of the study has shown that the computer aided instruction method of teaching enhance female students' interest in electronic libraries more than the modified lecture method of teaching. The test of hypotheses also revealed that there was no significant difference in the post test mean interest score of male and female students taught electronic libraries using computer aided instruction and those taught with modified lecture method.

Computer aided instruction and conventional method as was used in the study serve as a forum for all the students to learn. They were all given opportunity to interact with each other. They were asked to ask questions and taught without any form of gender bias. The use of computer aided instruction afforded the students the opportunity to learn electronic libraries concept in a way different from the classroom. The use of computer aided instruction favoured both the male and female. This implies that gender has no significant effect on interest of students in the Electronic Libraries Interest Scale (ELIS). These findings are in agreement with the finding of Orjika (2014) that gender was not a significant factor in student over all interest mean scores when taught biology using computer assisted instruction package.

\section{Conclusion}

The findings of this study showed that computer aided instruction has significant effect on students' interest in electronic libraries. CAI has been shown to be more effective and also helped to enhance students' interest and in electronic libraries concepts than the modified lecture method. Computer aided instruction method of teaching enhance female students' interest in electronic libraries more than the male students. In addition, there is no significant interaction effect of gender and teaching method on interest scores of students in electronic libraries.

In the light of the findings of the study, the following recommendations are made.

1. Lecturers should adopt the use of computer aided instruction in teaching of electronic libraries in tertiary institutions in order to enhance students' interest in electronic libraries.

2. Computer Aided Instruction should also be used by electronic libraries lecturers to enhance gender equity in interest of all students in Library and Information Science and other related disciplines.

3. The government should use the services of various bodies like the Nigerian Library Association (NLA), Nigeria Librarian Registration Council of Nigeria (NLRCN) and others to organize seminars, workshops and conferences to inform and train electronic libraries lecturers and 
Obiora Nwosu and Angela Ifeoma Ndanwu: Effect of computer aided instruction on students' interest in selected topics in electronic libraries course in federal tertiary institutions in Anambra State, Nigeria

other library and information science lecturers on the use of CAI in teaching and learning. They should also provide necessary facilities for the lecturers and students.

4. Special training on how to use computer aided instruction should always be organized for lecturers by the government, so as to help them become competent in the use of CAI in the teaching and learning process.

5. In-service training programmes such as seminar, in-service course, conferences and workshops on the use and operation of CAI should be organised for all practicing lecturers in tertiary institution to enable them develop up-to date computer competencies.

\section{References}

Adeyemi, B.A, (2012).Effects of computer assisted instruction ( CAI ) on students' achievement in social studies in Osun state, Nigeria. Mediterranean Journal of Social Sciences, 3(2), 269-277. Retrieved from

https://www.mcser.org/images/stor ies/2_journal/mjss_may_2012/adey emi_b.a_effets_of_cai.pdf.

Agbo N. M. (2016). Effects of computer assisted instruction on academic performance of technical college students in electrical installation and maintenance work in Enugu state. Unpublished Thesis, Vocational Education, Nnamdi Azikiwe University, Awka.

Bayo, E.O.(2016).The benefits of using electronic libraries resources in electronic libraries classroom.In Odogwu E.N. (Ed.).Introduction to electronic libraries.
Akwalbom:EssienPrinting Services.

David, D.C.(2017).The barriers to meaningful learning of electronic libraries. Abak, Nigeria: Bassey Publishers.

Dimgba, L.(2016). Modified lecture method. Retrieved from www . dimgbatom.com/

Essien, E.E., Akpan, O.E,\&Obot, I.M.(2015) Students" interest in social studies and academic achievement in tertiary institutions in cross rivers state, Nigeria Retrieved

fromhttp://www.eajournals.org/wpcontent/uploads/Students---Interest-in-Social-Studies-andAcademic-Achievement-inTertiary-Institutions-in-CrossRiver-State-Nigeria.pdf.

George, S.S.(2014). Seminar on e method and lectu IDemonstration method. Retrieved from http://bioradweekly.com/bbg/if-your-soulyourface-is-the-reflections-of-yourhealth.

Idowu, A.O. (2018). Ready-made software for Nigerian libraries. Old automation - projects; A survey of Existing facilities. Lagos librarian, 21(1\&2), 38-45.

Ismail, A. (2010). Benefits of CAI. Ukanafun:Aflo Publishers.

Kufi, A. (2015). Strategies for effective teaching and learning of electronic libraries: India, Sharma Publishers.

Mangal, S. K. \& Mangal U. (2009).Essential of educational technology PHI learning, New Delhi:Asoke K. Ghosh Press.

Martinez-Arellano, F. F. (2016). What is library and information science (LIS) in Latin American library schools. Retrievedfrom https://www.enssib.fr/bibliothequenumerique/documents/66403-what-

Library and Information Perspectives and Research, Volume 2, Number 1, 2020 
Obiora Nwosu and Angela Ifeoma Ndanwu: Effect of computer aided instruction on students' interest in selected topics in electronic libraries course in federal tertiary institutions in Anambra State, Nigeria

is-library-andinformation-sciencelis-in-latin-american-libraryschools.pdf.

Nwanne, S.C. \& Agommuoh, P.C.,(2017). Computer assisted instruction (CAI) on students' interest and achievement in physics in Imo state. IOSR Journal of Research and method in Education (IOSR$J R M E) 7(3) 53-58$. Retrieved from https://pdfs.semanticscholar.org/eb 22/68f6ab30c8db226c884cd0aff68 cb8e8e2c8.pdf.

Nwatu, K.(2018).Effects of multiple intelligence based instructional strategy on secondary school students' academic achievement and retention in chemistry. Unpublished Master's Thesis, Nnamdi Azikiwe University, Awka

Ocha, P. (2017). Gender. Retrieved from http;//Ochanet.Unocha.org/Ti/Gend er.

Ogbaga, O.A. (2016). Effect of brainstorming techniques on students' interest and achievement in biology in secondary school in Awka Education Zone.

Okoli, C.I. \& Onyeagba, J.N.(2016). Extent of environmental constraints to effective use of computer assisted instruction among business educators in tertiary institutions in Anambra State. Nigeria Journal of Business Education, 3(1).Pp 259 267.

Okwuduba, E. N. (2016).Effect of computer simulations on secondary school students academic achievement and interest in chemistry in Awka south local government area. Unpublished M.Ed thesis in Science Education, Nnamdi Azikiwe University, Awka.

Olarewaju, B.O. Better, E.S. \& Ugwuanyi, P.N. (2016).Effect of computer assisted instruction(CAI) on senior secondary school students' achievement in chemical reaction and equilibrium in Egbada Local Government Area of Oyo State. International Journal of Secondary Education, 14(4) Retrieved from http://www.sciencepublishinggroup .com/journal/paperinfo?journalid= $193 \&$ doi $=10.11648 / \mathrm{j} . \mathrm{ijsedu} .20160$ 404.11.

Olikeze, F. C.(2009). Effects of computerassisted instruction on secondary school students' cognitive achievement and interest in biology. Unpublished Ph.D thesis. University of Nigeria, Nsukkka

Olodu,F. (2012). Effects of CAI package on interest and achievement of preservice integrated Science Teachers at different levels of scientific literacy. M.Sc Thesis, Faculty ff Education, Nnamdi Azikiwe University, Awka.

Qureshi, F. (2019). Computer assisted instruction (CAI) and learning. Retrieved from https://www.slideshare.net

Sani, J.(2017). Introduction to electronic libraries. Uyo: Chico Publishers.

Suleiman, Q.,Hussain, I., Din, M.N, \& Igbal, K (2017). Effect of computer assisted instruction on students' academic achievement in physics at secondary school level. 8(7).

Townsend, F. E. (2015).Understanding electronic libraries for tertiary institutions. Uyo: Wilsonbooks Publishers.

Ubadi, C. (2011) Utilization of new learning technologies in teaching accounting by tertiary institution lecturers in Anambra state unpublished M.S.c thesis. Nnamdi Azikiwe University, Awka.

Ukala, G.(2018).Utilization of innovative teaching strategies for biology teaching in senior secondary school. African Journal of Science 
Obiora Nwosu and Angela Ifeoma Ndanwu: Effect of computer aided instruction on students' interest in selected topics in electronic libraries course in federal tertiary institutions in Anambra State, Nigeria

Technology and Mathematics Education (AJSTME),4(1).

Uwaleke, C.C.(2013). Analytical skills as a correlate of chemistry achievement among senior secondary school students in Anambra State. Unpublished M.ED thesis Nnamdi Azikiwe University, Awka.
Uwem, C.T., (2017). Introduction to internet and electronic libraries. Ikot Etim: Udom Publishers.

Yusuf, M.O, \& Afolabi, A.O, (2010). Effects of computer assisted instruction (CAI) on secondary school students' performance in biology. TOJET: The Turkish online Journal of Educational Technology, 9(1), 62-69. 